\title{
Influence of Manufacturing Methods on the Microbiological and Nutritional Characteristics of Kilichi, Dry Meat of Niger
}

\author{
Sabo Haoua Seini ${ }^{*}$, Aminou Illia Mama Nafiou ${ }^{2}$, Bako Aminatou Maazou ${ }^{3}$, \\ Hassimi Sadou', Amoukou Ibrahim ${ }^{4}$, Musambahou Malam Alma ${ }^{2}$, \\ Ramatou Seini Sidikou ${ }^{5}$, Mahamane Saadou ${ }^{5}$ and Mamoud Moussa Ramatou ${ }^{6}$
}

\author{
${ }^{1}$ Health and Food Safety, Study and Improvement of Traditional Processes, \\ Department of Chemistry, Faculty of Science and Technology / \\ Abdou Moumouni University of Niamey, Niger \\ ${ }^{2}$ Department of Chemistry, Faculty of Science and Technology / Abdou Moumouni University \\ of Niamey, Niger \\ ${ }^{3}$ Department of Applied Biological Sciences, Faculty of Health Sciences / Abdou Moumouni \\ University of Niamey, Niger \\ ${ }^{4}$ Department of Crop Production, Faculty of Agronomy, Abdou Moumouni University of \\ Niamey, Niger \\ ${ }^{5}$ Department of Biology, Faculty of Science and Technology / Abdou Moumouni University of \\ Niamey, Niger \\ ${ }^{6}$ Institute of Public Health, Niamey, Niger
}

*Corresponding author

\begin{tabular}{|l|}
\hline K e y w o r d s \\
Kilichi, Process, Quality, \\
$\begin{array}{l}\text { Microbiological, } \\
\text { Nutritional, Improvement, } \\
\text { Regulations, Niger }\end{array}$ \\
\hline Article Info \\
\hline $\begin{array}{l}\text { Accepted: } \\
\text { 04 November } 2018 \\
\text { Available Online: } \\
\text { 10 December } 2018\end{array}$
\end{tabular}

A B S T R A C T
In Niger, the kilichi, thin slices of dried meat, is one of the most popular products both domestically and internationally. Our objective through this study is to contribute to the improvement of the sanitary quality of the kilichi of Niger. For this purpose, the microbiological and nutritional characteristics of 3 variants ("Fari", "Ja" and "Rumuzu" for both methods, for a total of 6 products, including 3 from a modern process and 3 from a Traditional processes are compared: From a microbiological point of view, the desired microorganisms are mesophilic aerobic flora, total coliforms, faecal coliforms, Salmonella, yeasts and molds, and anaerobic sulphuro-reductive levels in accordance with national standards. are fractionated by the determination of calcium and zinc contents. The results of the microbiological analyzes Revealed That kilichi variants derived from the traditional method are loaded with microorganisms Significantly more than Those derived from the modern method and by aussi standards. Indeed, the results of kilichi "fari 1"and "rumuzu 1 "are clearly above the norms for all tested germs, and "fari 2"and "rumuzu 2" for the first two germs. Faecal coliforms have been found, although they are substandard. The kilichi "ja 1"has exceeded the norms for all the first two germs but is below the kilichi "ja 2"results. These results are encouraging for the modern method, despite the measures taken. However, hygiene needs to be strengthened for a better health of kilichi of Niger. 


\section{Introduction}

Niger, a breeding country par excellence, is a major producer of meat (Zakari, 2010). Meat processing in Kilichi is an economic activity conducted by meat professionals throughout the country, in both rural and urban areas. It is a food product that is the pride of Nigerians, because it is one of the precious and authentic gifts of the soil that Nigerians like to offer to foreigners during their travels. For example, in 2013, $6092 \mathrm{Kg}$ of Kilichi were exported (Beidari and Mounkaila 2014). It is a meat product, usually beef, dried and grilled into strips seasoned with a spicy peanut paste (Yacoube, 2009; Kalilou, 1994). In Niger, its manufacture is an artisanal activity commonly practiced by butchers. It is a potentially interesting product for the Sahelian markets. It is popular in both rural and urban areas (URL: fao.org). Kilichi meat processors, who are usually butchers by profession, have acquired the technique of processing at $98 \%$ by inheritance and that from generation to generation for many years.

In fact, these Kilichi professionals, who had remained for a long time in anonymity and in the informal, thought of organizing themselves. In 2012, they created an association called "Nigerian Association for the Promotion of Kilichi (ANIPROK)". It is a national association of which in principle all professionals of Kilichi are members with representations at National level.

This study is a research and action conducted by the University of Niamey and the Directorate General of Production and Animal Industries (DGPIA) to contribute to the drafting of the specifications for the actors of the kilichi sector for a better regulation of the sector outside the Niger scrub. In addition, some studies have shown a high microbial load in products derived from traditional methods (Mbawala et al., 2010; FAO, 2014).
The present study on geographical indications of Kilichi in Niger comes at a time when several development programs are intervening in the sector, focusing on the transformation of meat into Kilichi, or in general, the processing of agricultural products. sylvo-pastoral and fisheries in their plan of action. Some producers are trying to replicate the kilichi production technique. However the results are not always satisfactory.

The following objectives are assigned to this study: To determine the organoleptic and microbiological characteristics of Kilichi resulting from modern and traditional methods; Determine the nutritional value of Kilichi; Compare the analytical results of the two types of Kilichi production (modern and traditional).

\section{Materials and Methods}

\section{Animal material}

The main raw material is boneless, good quality red meat, which does not have too much fat compared to meat.

The meat for implementation is purchased at the slaughterhouse.

\section{Production kilichi}

Three kilichi manufacturing variants are implemented by method. That is a total of 6 samples for both traditional and modern methods. The three variants are: kilichi 'Ja'; kilichi 'fari' and kilichi Rumuzu. They have the following characteristics:

Kilichi 'Ja': red color, dry appearance, thick slices in the form of flat sheets of various sizes;

Kilichi 'fari': whitish color, dry appearance, thick slices in the form of flat sheets of various sizes; 
Kilichi Rumuzu: dark brown color, dry appearance, thin slices in the form of flat sheets of various sizes.

\section{Microbiological analysis methods}

Samples immediately produced are transported to the laboratory for microbiological analyzes to avoid contamination. The desired germs and methods of analysis are summarized in the following table 1 .

\section{Nutritional analysis methods}

The water content was determined on the mill by oven drying according to the method (AOAC, 1984). Ashes are obtained after dry mineralization of the previously dried mill (AOAC, 1984). Total proteins are determined according to the KJELDAHL reference method (Wolf, 1968). The lipids are extracted by soxhlet and percolation of hexane according to the IUPAC method (1968). The ashes are solubilized in hydrochloric acid. The zinc and calcium contents are determined by atomic absorption spectrophotometry.

\section{Results and Discussion}

\section{Results of microbiological analyzes}

The results obtained are compared to the standards of the Standardization Council, which has defined the normal characteristics of Kilichi from a microbiological point of view. According to the Council, the kilichi must have:

Aerobic total mesophilic flora less than 10,000 / $\mathrm{g}$ of product;

A total coliform level of less than $100 / \mathrm{g}$ of product;

A yeast and mold load of less than $100 / \mathrm{g}$ of product and
Absence of mold visible to the naked eye;

A sulfo-reducing anaerobic rate of less than 10 / $\mathrm{g}$ of product

Absence of salmonella in $25 \mathrm{~g}$ of product

Results of microbiological analyzes of samples from the modern kilichi transformation method

This variant of kilichi is charged for the first two germs. If not for the last five, the values obtained are lower than the norms; all the same it is about an unfit food unhealthy.

The observations of the above variant are valid here, except that enterococci have not been observed in Ja1.

The kilichi rumuzu 1 is acceptable from a point of view Microbiological.

Results of microbiological analyzes of samples from the traditional kilichi transformation method

The kilichi fari2 is a loaded variant and there is even the presence of fecal coliforms. It is considered an unhealthy food.

Ja2, after microbiological analysis shows a charge that makes it unfit for consumption

The kilichi rumuzu 2 as before is also unfit for consumption. Fortunately, the absence of faecal coliforms is noted.

\section{Results of nutritional analyzes}

From a nutritional point of view, water contents range from 6.96 to $8.37 \%$;for proteins from $37.47 \%$ to $62.02 \%$;lipids from 10.85 to $33.35 \%$ and ashes from 2.22 to $3.21 \%$.

There is a great variability between the 
variants for the two minerals. Indeed, zinc levels range from 62.05 to $439.18 \mathrm{mg} / 100 \mathrm{~g}$ and calcium from 99.34 to $6273.68 \mathrm{mg} / 100 \mathrm{~g}$.

This part is devoted to the comparison of the finished products resulting from the traditional method and those resulting from the standard method on the main criteria of quality namely the organoleptic characteristics, the safety, and the price.

It is the inability of the food product to endanger the health of the consumer. This variable will be evaluated by the results of microbiological analyzes.

This comparative table 2 shows that the Kilichi "fari 1"results are clearly above the norms for all the germs tested, which is a direct consequence of the hygiene measures taken during the processing of this food. While the results of Kilichi "fari 2"have largely exceeded the norms for the first two germs. Faecal coliforms have even been found, although inferior to the norms, this can be avoided by washing hands with soap at the exit of the toilets. The food is classified unfit for human consumption, in relation to the microbial load it contains, can cause serious health problems.

This comparative table 3 shows that the Kilichi "ja 1"results exceeded the norms for all the first two germs but are below the "ja 2"Kilichi results, which is encouraging. It remains to find ways to improve the safety of modern kilichi and lower results in -Dessous standards (Table 4-12).

As for "fari 1"the results of Kilichi "ja 2"have largely exceeded the norms. The food is also classified as unfit for human consumption, with regard to the microbial load it contains, can cause serious health problems. Here too, the Kilichi "rumuzu 1"results are clearly above the norms for all the tested organisms, which is a direct consequence of the hygiene measures taken during the processing of this food. While the results of Kilichi "rumuzu 2"have largely exceeded the norms for the first two germs. The food is classified as unfit for human consumption, with regard to the microbial load it contains. If one refers to at critical points related to the five "m's" and their control the results lead to the following comments:

Table.1 Summary methods of microbiological analyzes

\begin{tabular}{|l|l|l|l|l|}
\hline Wantedsprouts & Used media & $\begin{array}{l}\text { Seeding } \\
\text { techniques }\end{array}$ & $\begin{array}{l}\text { Incubation } \\
\text { temperature }\end{array}$ & $\begin{array}{l}\text { Incubation } \\
\text { time }\end{array}$ \\
\hline Mesophilicaerobicflora & $\begin{array}{l}\text { FCA + GB } \\
15 \mathrm{ml}+5 \mathrm{ml}\end{array}$ & Double flood & $30^{\circ} \mathrm{C}$ & $24 \mathrm{H}-72 \mathrm{H}$ \\
\hline Total coliforms & $\begin{array}{l}\text { VRBL / mac } \\
\text { EFA }\end{array}$ & streaks & $30^{\circ} \mathrm{C}$ & $24 \mathrm{H}-48 \mathrm{H}$ \\
\hline Fecalcoliforms & $\begin{array}{l}\text { VRBL / EMB } \\
\text { EFA }\end{array}$ & streaks & $44^{\circ} \mathrm{C}+/-1$ & $24 \mathrm{H}-48 \mathrm{H}$ \\
\hline Salmonella & $\begin{array}{l}\text { Selenite-Rap } \\
\text { Hektoen }\end{array}$ & streaks & $37^{\circ} \mathrm{C}$ & $24 \mathrm{H}-48 \mathrm{H}$ \\
\hline Yeasts and molds & OGA & staggering & $37^{\circ} \mathrm{C}$ & $24 \mathrm{H}-48 \mathrm{H}$ \\
\hline $\begin{array}{l}\text { Anaerobic Sulfur } \\
\text { Reduction Rate }\end{array}$ & TSN (20ml) & In the mass & & $24 \mathrm{H}-48 \mathrm{H}$ \\
\hline
\end{tabular}


Table.2 Results of kilichi "fari 1"analyzes

\begin{tabular}{|l|l|l|}
\hline seeds & Results & standards \\
\hline Aerobic total mesophilicflora & $>100000 / \mathrm{g}$ & $\leq 25000 / \mathrm{g}$ \\
\hline Total coliforms & $<100 / \mathrm{g}$ & $<1000 / \mathrm{g}$ \\
\hline Fecalcoliforms & $00 / \mathrm{g}$ & $<10 / \mathrm{g}$ \\
\hline Yeast and moldload & Absence & $<1000 / \mathrm{g}$ \\
\hline Anaerobic Sulfur Reduction Rate & $00 / \mathrm{g}$ & $<100$ colonies / g \\
\hline salmonella & Absence & $00 / 25 \mathrm{~g}$ \\
\hline Enterococcus & $<10 / \mathrm{g}$ & $<100000 / \mathrm{g}$ \\
\hline
\end{tabular}

Table.3 Results of Kilichi "ja 1"analyzes

\begin{tabular}{|l|l|l|l|}
\hline seeds & Results & standards & \\
\hline total mesophilic aerobicflora & $>150000 / \mathrm{g}$ & $\leq 25000 / \mathrm{g}$ \\
\hline total coliforms & $>1000 / \mathrm{g}$ & $<1000 / \mathrm{g}$ & \multirow{2}{*}{$\begin{array}{l}\text { Acceptable } \\
\text { sanitation }\end{array}$} \\
\hline Fecal coliforms & $00 / \mathrm{g}$ & $<10 / \mathrm{g}$ & \\
\hline Yeast and moldload & Absence & $<1000 / \mathrm{g}$ \\
\hline Anaerobic Sulfur Reduction Rate & $00 / \mathrm{g}$ & $<100$ colonies /g \\
\hline salmonella & Absence & $00 / 25 \mathrm{~g}$ \\
\hline Enterococcus & $00 / \mathrm{g}$ & $<100000 / \mathrm{g}$ & \\
\hline
\end{tabular}

Table.4 Results of Kilichi Rumuzu 1 Analyzes

\begin{tabular}{|c|c|c|c|}
\hline Seeds & Results & standards & \multirow{8}{*}{$\begin{array}{l}\text { Acceptable } \\
\text { sanitation }\end{array}$} \\
\hline Total mesophilic aerobicflora & $>1000 / g$ & $\leq 25000 / \mathrm{g}$ & \\
\hline Total coliforms & $>10 / \mathrm{g}$ & $<1000 / \mathrm{g}$ & \\
\hline Fecal coliforms & $00 / g$ & $<10 / g$ & \\
\hline Yeast and moldload & Absence & $<1000 / \mathrm{g}$ & \\
\hline Anaerobic Sulfur Reduction Rate & $00 / g$ & $<100$ colonies / g & \\
\hline Salmonella & Absence & $00 / 25 \mathrm{~g}$ & \\
\hline Enterococcus & $00 / \mathrm{g}$ & $<100000 / \mathrm{g}$ & \\
\hline
\end{tabular}


Int.J.Curr.Microbiol.App.Sci (2018) 7(12): 231-241

Table.5 Results of Kilichi "fari 2"analyzes

\begin{tabular}{|l|}
\hline seeds \\
\hline total mesophilic aerobicflora \\
\hline total coliforms \\
\hline Fecal coliforms \\
\hline Yeast and moldload \\
\hline Anaerobic Sulfur Reduction Rate \\
\hline salmonella \\
\hline Enterococcus
\end{tabular}

\begin{tabular}{|l|l|}
\hline Results & standards \\
\hline$>25000 / \mathrm{g}$ & $\leq 25000 / \mathrm{g}$ \\
\hline$>10,000 / \mathrm{g}$ & $<1000 / \mathrm{g}$ \\
\hline$<10 / \mathrm{g}$ & $<10 / \mathrm{g}$ \\
\hline Absence & $<1000 / \mathrm{g}$ \\
\hline $00 / \mathrm{g}$ & $<100$ colonies / \\
\hline Absence & $00 / 25 \mathrm{~g}$ \\
\hline$>10,000 / \mathrm{g}$ & $<100000 / \mathrm{g}$ \\
\hline
\end{tabular}

Unhealthy food

Table.6 Results of Kilichi "ja 2"analyzes

\begin{tabular}{|l|l|l|l|}
\hline seeds & Results & standards & \\
\hline total mesophilic aerobicflora & $>100000 / \mathrm{g}$ & $\leq 25000 / \mathrm{g}$ & $\begin{array}{l}\text { Food unfit for } \\
\text { human } \\
\text { consumption }\end{array}$ \\
\hline total coliforms & $>1000 / \mathrm{g}$ & $<1000 / \mathrm{g}$ & \\
\hline Fecal coliforms & $<10 / \mathrm{g}$ & $<10 / \mathrm{g}$ \\
\hline Yeast and moldload & Absence & $<1000 / \mathrm{g}$ \\
\hline $\begin{array}{l}\text { Anaerobic Sulfur Reduction } \\
\text { Rate }\end{array}$ & $00 / \mathrm{g}$ & $<100$ colonies /g \\
\hline salmonella & Absence & $00 / 25 \mathrm{~g}$ \\
\hline Enterococcus & - & $<100000 / \mathrm{g}$ & \\
\hline
\end{tabular}

Table.7 Results of Kilichi Rumuzu 2 Analyzes

\begin{tabular}{|l|l|l|l|}
\hline seeds & Results & standards & \\
\hline total mesophilic aerobicflora & $>50000 / \mathrm{g}$ & $\leq 25000 / \mathrm{g}$ & $\begin{array}{l}\text { Food unfit } \\
\text { for human } \\
\text { consumption }\end{array}$ \\
\hline total coliforms & $>10,000 / \mathrm{g}$ & $<1000 / \mathrm{g}$ & \\
\hline Fecalcoliforms & $<00 / \mathrm{g}$ & $<10 / \mathrm{g}$ \\
\hline Yeast and moldload & Absence & $<1000 / \mathrm{g}$ \\
\hline Anaerobic Sulfur Reduction Rate & $00 / \mathrm{g}$ & $<100$ colonies $/ \mathrm{g}$ \\
\hline salmonella & Absence & $00 / 25 \mathrm{~g}$ \\
\hline Enterococcus & $>10,000 / \mathrm{g}$ & $<100000 / \mathrm{g}$ \\
\hline
\end{tabular}


Table.8 Water content, proteins, lipids, and ash in g / 100g of Kilichi

\begin{tabular}{|l|c|c|c|c|}
\hline products & Water & Protein (\% MS) & Lipids (\% MS) & Ash (\% MS) \\
\hline F1 & 8.37 & 50.75 & 20.95 & 2.31 \\
\hline F2 & 7.27 & 49.82 & 30,01 & 3.01 \\
\hline J1 & 7.77 & 37.47 & 18.11 & 3.21 \\
\hline J2 & 8.04 & 51.52 & 33.35 & 2.52 \\
\hline R1 & 6.96 & 62.02 & 10.85 & 2.22 \\
\hline R2 & 7.18 & 55.78 & 29,21 & 2.91 \\
\hline
\end{tabular}

Table.9 Content of $\mathrm{Ca}$ and $\mathrm{Zn}$ in mg / 100g dry matter of kilichi

\begin{tabular}{|l|c|c|c|c|c|c|}
\hline Elements & F1 & F2 & J1 & J2 & R1 & R2 \\
\hline Ca & 3776.26 & 6273.68 & 119.33 & 162.43 & 99.34 & 6602.94 \\
\hline Zn & 62.05 & 408.16 & 383.68 & 261.92 & 439.18 & 68.45 \\
\hline
\end{tabular}

Table.10 Comparison of the two "fari"

\begin{tabular}{|l|}
\hline Seeds \\
\hline total mesophilic aerobicflora \\
\hline total coliforms \\
\hline Fecal coliforms \\
\hline Yeast and moldload \\
\hline Anaerobic Sulfur Reduction Rate \\
\hline salmonella \\
\hline Enterococcus \\
\hline
\end{tabular}

\begin{tabular}{|l|l|l|}
\hline "Fari 1" & standards & "Fari 2 " \\
\hline$>10000 / \mathrm{g}$ & $\leq 25000 / \mathrm{g}$ & $>25000 / \mathrm{g}$ \\
\hline$<100 / \mathrm{g}$ & $<1000 / \mathrm{g}$ & $>10,000 / \mathrm{g}$ \\
\hline $00 / \mathrm{g}$ & $<10 / \mathrm{g}$ & $<10 / \mathrm{g}$ \\
\hline Absence & $<1000 / \mathrm{g}$ & Absence \\
\hline $00 / \mathrm{g}$ & $<100$ colonies / g & $00 / \mathrm{g}$ \\
\hline Absence & $00 / 25 \mathrm{~g}$ & Absence \\
\hline$<10 / \mathrm{g}$ & $<100000 / \mathrm{g}$ & $>10,000 / \mathrm{g}$ \\
\hline
\end{tabular}

Table.11 Comparison of the two "ja"

\begin{tabular}{|l|}
\hline Seeds \\
\hline Total mesophilic aerobicflora \\
\hline Total coliforms \\
\hline Fecal coliforms \\
\hline Yeast and moldload \\
\hline Anaerobic Sulfur Reduction Rate \\
\hline Salmonella \\
\hline Enterococcus \\
\hline
\end{tabular}

\begin{tabular}{|l|l|l|}
\hline "Ja 1" & standards & "Ja 2" \\
\hline$>50000 / g$ & $\leq 25000 / g$ & $>100000 / g$ \\
\hline$>1000 / g$ & $<1000 / g$ & $>1000 / g$ \\
\hline $00 / g$ & $<10 / g$ & $<10 / g$ \\
\hline Absence & $<1000 / g$ & Absence \\
\hline $00 / g$ & $<100$ colonies /g & $00 / g$ \\
\hline Absence & $00 / 25 \mathrm{~g}$ & Absence \\
\hline $00 / g$ & $<100000 / g$ & - \\
\hline
\end{tabular}


Table.12 Comparison of the two "Rumuzu 1"

\begin{tabular}{|l|l|l|l|}
\hline Seeds & "Rumuzu 1" & standards & "Rumuzu 2" \\
\hline total mesophilic aerobicflora & $>1000 / \mathrm{g}$ & $\leq 25000 / \mathrm{g}$ & $>50000 / \mathrm{g}$ \\
\hline total coliforms & $>10 / \mathrm{g}$ & $<1000 / \mathrm{g}$ & $>10,000 / \mathrm{g}$ \\
\hline Fecal coliforms & $00 / \mathrm{g}$ & $<10 / \mathrm{g}$ & $<00 / \mathrm{g}$ \\
\hline Yeast and moldload & Absence & $<1000 / \mathrm{g}$ & Absence \\
\hline Anaerobic Sulfur Reduction Rate & $00 / \mathrm{g}$ & $<100$ colonies /g & $00 / \mathrm{g}$ \\
\hline Salmonella & Absence & $00 / 25 \mathrm{~g}$ & Absence \\
\hline Enterococcus & $00 / \mathrm{g}$ & $<100000 / \mathrm{g}$ & $>10,000 / \mathrm{g}$ \\
\hline
\end{tabular}

\section{Middle}

From the barn to the consumer's table, the Kilichi processing environment is a real source of contamination that must be mastered in order to achieve a healthy food that meets the sanitary standards set.

\section{Raw material}

The raw material of Kilichi is meat. However, it has been shown above that the medium affects the quality of the meat. To improve the quality of Kilichi meat safety must be guaranteed from the beginning to the end of the process.

\section{Workforce}

Sick workers who handle meat and noncompliance with hygiene measures are the most common sources of contamination of food-borne diseases.

\section{Equipment}

From the knife used to slaughter the animal to the plate in which the Kilichi is served by passing the means of transport, the tables, the containers, the knives, the displays of the transformers and all the rest are sources of direct contamination of the Kilichi.

\section{Method}

The kilichi transformation method has not changed much over the years. And it is not appropriate to avoid contamination and thus ensure the safety of Kilichi.

At the end of the critical-point analysis, the safety of the kilichi can be obtained by inexpensive gestures such as washing hands with soap, cleaning and disinfecting equipment, and wearing appropriate work clothes.

In the literature very little work on the microbiological analysis of kilichi is met. Nevertheless, in Nigeria, a bacteriological analysis concerned the kilichi of 3 localities (AbdulMajeed, 1996). Five bacterial species in total, namely: Staphylococcus aureus, Pseudomonas aeruginosa, Escherichia coli, Klebsiella pneumoniae and Bacillus subtilis were isolated. Content Total sample bacteria 
ranged from $2.4 \times 104$ to $3.5 \times 104$ colony forming units / g, enterobacteria from $2.61 \mathrm{x}$ 104 to $2.90 \times 104$ colony forming units / g, the number of $S$. aureus from $1.6 \times 104$ to $2.05 \times 104$ colony forming units/g. E. coli in all samples was lowest, ranging from $1.2 \mathrm{x}$ 101 to $3.8 \times 101$ colony forming units/g.

Staphylococcus aureus enterotoxin is an extremely potent gastrointestinal toxin; 100 ng is enough to cause symptoms of intoxication (Evenson et al., 1988; Rasooly, 1997). The high number of Enterobacteriaceae in the samples indicates a possibility of enteric contamination (Brown and Baird-Parker, 1982).

The number of E. coli between $1.2 \mathrm{X} 101$ and $3.8 \times 101$ colony forming units / $\mathrm{g}$ for samples from all sources is high. This is a public health concern given the role of E. coli in foodborne infection (Goepfert, 1976).

\section{Niger samples should be searched for these} bacteria

In Cameroon, of the four spicy and uncooled kilichi samples, seven traditional manufacturing and sales sites in the city of Ngaoundéré (North Cameroon) are being studied (Mbawala, 2010). The aim of this study is to test the hypothesis that the total microbial load of kilichi samples and the type of germ they contain would influence the hygienic quality of the product.

This is a hus that mesophilic aerobic flora, coliforms, yeasts and molds, Staphylococcus aureus, Clostridium sulphite, Bacillus cereus and Salmonella spp. Were counted on these samples. Results show that $33.34 \%$ and $50 \%$ of kilichi pepper samples are infected with $B$. cereus and Salmonella spp., respectively, while $83.34 \%$ of unpimed kilichi samples are contaminated with these two microorganisms. The average level of contamination u kilichi non spiced is 0.43 (sulfite-reducing Clostridium) with a maximum value of 0.63 .

These high values represent risks food poisoning of consumers as well as samples from Niger. They also noted that regardless of the type of microorganism counted, all nonchili kilichi samples are more contaminated than chipped kilichi samples (Mbawala, 2010).

As regards the nutritional value, according to the literature, in general the values obtained in Niger are found in the intervals encountered. Indeed, the chemical characteristics of the kilichi all variants combined are as follows: water content: $7-20 \%$, protein content: 5 to $70 \%$, lipid content: $15-20 \%$ and iron content 35\% (Beidari et al., 2013). The contents AC and zn are very interesting and can meet the needs of the population because their $\mathrm{s}$ deficiencies pose problems public health. The thicknesses of the lamellae influence also $\mathrm{ce}$ s contents.

The main ingredients (peanut paste or nutmeg paste, water, spices mainly composed of, black pepper, anise, nutmeg, garlic, chilli, soumbala, ginger, onion, cooking salt, red dye, clove, flavor (aroma maggi) utiized in the manufacture of kilichi can influence its nutritional value. In these ingredients, we find protein - oleaginous sources (peanut, nutmeg, soumbala) and sources of minerals (ginger, pepper, pepper, etc.).

The results of this study can be used to supplement the specifications of the Niger kilichi from a microbiological and nutritional quality point of view.

At the end of this study, the desired microorganisms were mesophilic aerobic flora, total coliforms, fecal coliforms, Salmonella, yeasts and molds, and anaerobic sulfuro-reducing ratio for 6 products, 
including 3 variants for the modern method and 3 for the method. Traditional Microbial loads above Nigerian standards are observed in the traditional method. Apart from the solar dryer used for the modern method, strict hygiene measures are also observed. By respecting the good practices of hygiene and sanitation the sanitary quality of the kilichi of Niger can be improved and be competitive internationally.

Regarding, the nutritional value, the raw material used being meat, is a good source of animal protein and minerals. Ingredients of plant origin reinforce these potentialities. So the kilichi of Niger is a good source of macro and micronutrients.

The results from our study show that Kilichi's modern processing method is very effective in improving the safety of this product, which Nigerians and foreigners alike are experiencing.

\section{References}

Abdul Majeed I. Raji. 1996. Bacteriological Quality of Dried Sliced Beef (Kilichi) Sold In Ilorin Metropolis, J. Appl.Sci.About.Mgt. March, 2006 Vol. 10 (1) 93- 96

AOAC; Washington DC. 1984. Edit P24003.

Brown, MH, Baird-Parker, AC. 1982. The microbiological examination of meat. In: Brown, MH (Ed.), Meat Microbiology. Applied Science Publishers, London, pp. 423-520.

Evenson, MI, MW Hinds, RS Bernstein, and MS Bergdoll. 1988 of a large outbreak of staphylococcal food poisoning involving chocolate milk. Int.J. Food Microbiol. 7: 311-316

Goepfert, JM. 1976. The aerobics count, coliform and Escherichia coli content of raground beef at retail level. J. Food Prot. 39, 175-178.

http://news.aniamey.com/h/1178.html «Pastoralism in Niger: Livestock farming, a sector of wealth, but full of risks" viewed on 26/04/2015 21:34

International Union for Pure and Applied Chemistry (IUPAC). 1968. Unified analytical methods by the fat section of the International Union of Pure Applied Chemistry, IB 2.

Kalilou Souley. 1994. Comparative diagrams of making different types of Kilichi "ABDOU Moumouni University of Niamey. November 1994

Mbawala A., B. Daoudou and MB. 2010. Ngassoum, microbiological quality of kilishi (dried meat product) produced in the city of Ngaoundéré (Cameroon), TROPICULTURA，2010，28，3，153160

Official Analytical Chemist. 1984. Official Method of Analysis Edit. AOAC; Washington DC. P14006.

Rasooly, L., Rose, NR; Shah, DB and Rasooly, A. (1997). In Vitro Assay of Staphylococcus aureus Enterotoxin a Activity in Food. Appl. Env. Microbiol. 63: $2361-2365$

Seybou B and Mahamadou M. 2013. Study for the realization of geographical indications and specifications of Kilichi in Niger", p.15.

Wolf J.P. (1968) Manual of analysis of fatty substances: Protein matters. Edit. AZOULAYE.P552.

Yacouba Issa. 2009. Analysis of traditional meat processing techniques in Kilichi in the urban commune of Madaoua (Republic of Niger)

Zakary Rhissa. 2010. Review of the livestock sector in Niger February 


\section{How to cite this article:}

Sabo Haoua Seini, Aminou Illia Mama Nafiou, Bako Aminatou Maazou, Hassimi Sadou, Amoukou Ibrahim, Musambahou Malam Alma, Ramatou Seini Sidikou, Mahamane Saadou and Mamoud Moussa Ramatou. 2018. Influence of Manufacturing Methods on the Microbiological and Nutritional Characteristics of Kilichi, Dry Meat of Niger. Int.J.Curr.Microbiol.App.Sci. 7(12): 231-241. doi: https://doi.org/10.20546/ijcmas.2018.712.029 